\title{
What the Meaning of Success in Female Entrepreneurs' Perceptions? An Interview-Based Study
}

\author{
Shofia Amin \\ Faculty of Economics and Business, Universitas Jambi, Indonesia \\ E-mail: shofiaamin@unja.ac.id
}

Fitri Widiastuti

Faculty of Economics and Business, Universitas Jambi, Indonesia

Fitriaty

Faculty of Economics and Business, Universitas Jambi, Indonesia

Received: Aug. 12, 2019 Accepted: Oct. 18, 2019 Online published: Oct. 28, 2019

doi:10.5296/ijhrs.v9i4.15260 URL: https://doi.org/10.5296/ijhrs.v9i4.15260

\begin{abstract}
Entrepreneurs are those who are brave and willing to take a risk for success or failure. The idea of success itself has many meanings and factors behind it. By using qualitative design, this research aimed at exploring the meaning of success for female entrepreneurs and the factors that influenced their success. Data were collected through an in-depth interview with four female entrepreneurs who owned culinary business. Findings showed that the participants perceived the definition of success as the stage when they can meet financial needs such as ownership of house, vehicles and able to go Umrah. Then the financial success will shift to psychological success which formed as an inner satisfaction because they can help people by employing them, share and give some to others or families. To be successful, personal factors, internal and external support from family are really matter. Understanding the meaning of success and the factors influenced it will have implications for determining strategy in achieving success.
\end{abstract}

Keywords: financial success, psychological success, social success

\section{Introduction}

The improved education levels of women and gender equality shifted the role of women from 
being just housewives to being breadwinners. This fact can be seen that many more women who become workforce both as office workers and as self-employed by establishing their own business as an entrepreneur. As an entrepreneur, women also have significant roles in world economic development.

In 2010, almost $42 \%$ of entrepreneurs in the world were women (Global Entrepreneurship Monitor 2010). Based on the results of a report by International Finance Corporation (2016) in Indonesia, especially in urban areas, there were $52.9 \%$ of micro-enterprises, $50.6 \%$ of small businesses and $34.0 \%$ of medium businesses were owned by women. Overall, even though the number of micro and small-scale women entrepreneurs is more than half of the total SMEs in Indonesia, their contribution to the new GDP is 9.1\%. This condition is due to the various limitations and obstacles they face.

Based on the result of the initial survey and supported by the results of previous research (Hadiyati 2010) the main classical problem small-scaled entrepreneurs are encountering is the financial and marketing issue. Research on the topic of entrepreneurship has also been widely carried out, but research on women entrepreneurs is still challenged (Jennings \& Brush 2013). Even if they involve female entrepreneurs, it is mostly related to the reasons why women become entrepreneurs (Sarri \& Trihopoulou 2005; Raman, Anantharaman. \& Jayasingan 2008; Alam, Jani \& Omar 2011) or associated with obstacles female entrepreneurs are facing (Brindley 2005; Goyal \& Parkash 2011; Kurniawan, Jalaludin \& Hastuti 2015). In particular, since women have different mindsets than their counterparts, they are more sensitive, gentle and more listening to conscience (Nandy \& Kumar 2014). Yet, there are still very few researches that highlight the female micro-entrepreneurs and relate them to the perceptions of the measure of their success and the factors which influence their success.

Albeit the term of success is well known to everyone, the definition is diverse. It has different meanings for different people depending on the context of the personal definition (Mabhungu $\&$ Der Poll 2017). In today's modern context, success in a career is regarded as a subjective construct (Heslin 2005; Park 2010; Srikanth \& Israel 2012). Success in a career is no longer perceived objectively with the improvement of financial aspect and position. The meaning of success has shifted from objective to subjective perception. Success is felt more inwardly as measured by the subjective judgments of each individual.

Understanding the meaning of success and its influential factors are crucial for further study in the context of micro-entrepreneurship. Better understanding of the success is expected to contribute inputs to the entrepreneurs themselves and local government in determining the strategy of the creative economy development from the perspective of human resource management and individual behavior. From the academic perspective, the results of the present research will provide some insight into the success of small-scaled and micro-entrepreneurs who can deliver practical contribution for the independent business management.

\section{Literature Review}

An entrepreneur is a person who has a particular spirit and ability in creating and innovating. 
Such creative and innovative skills are reflected in the ability and willingness to start performing business, the ability to do something new, the willingness and ability to seek opportunities, the ability and courage to take risks and the ability to develop ideas and gather human resources (Afiff 2012).

Despite a micro, small, and medium-scaled business, frequently, the owners, at the same time act as workers. In general, there is a fundamental difference between small-scaled business owners and entrepreneurs. A small business owner is an individual who establishes and manages a business for personal purposes as his primary source of income. Thus, his business is often a reflection of his personality. Meanwhile, the entrepreneurs establish and manage their business for profit and growth purposes. Entrepreneurs are characterized by innovative behavior and strategic management in their business (Carland, Hoy, Boulton \& Carland 1984).

Although it has subjective meaning, achieving success is everyone's aspiration. People will see that others are successful based on financial achievement and position, whereas for themselves, they will feel successful when they feel inner satisfaction with what they have done, in spite of the financial aspect and position, they do not experience a significant improvement. Therefore, there is no agreement on an accurate measure of success. The achievement of any form of success can be both subjectively and objectively determined (Fisher, Maritz \& Lobo 2014).

In the entrepreneurs' perspective, the meaning of success is greatly influenced by their economic background, which eventually, it will affect their motivation in running their business. Broadly speaking, micro- and small entrepreneurs with lower income background will measure the level of success according to the extent of improvement in the financial aspect, while those from middle to higher income will perceive the success based on psychological aspects such as, self-esteem and self-actualization (Benzing, Chu \& Kara 2009). On the other hand, Baruch (2006) argued that money is not the main motivator is true, provided that the need for money has been met. Entrepreneurial success may also have a temporal aspect; it is achieved at this point in time and thus can be transient in nature (Fisher et al. 2014).

However, if these basic necessities have not yet been satisfied, earning money is the ultimate goal and its measure. Thus, initially, the success of a career will be judged based on the achievement of the fulfillment of basic needs, such as the financial aspect. Subsequently, it will shift to the achievement of psychological satisfaction, such as self-actualization and social aspects (Abele \& Spurk 2009; Amin 2012).

Entrepreneurs are regarded to be successful when they think, come up with something new or do something old with new ways (Zimmerer \& Scarborough 2008). It is needed creativity and innovative thinking in producing new or improving existing products to ensure their business with remain successful (Mat Rashid, Che Ngah, Mohamed \& Mansor 2015). The achievement of the success, according to Zimmerman and Jiang (2009) is influenced by the capital owned by the entrepreneurs themselves, which consists of three aspects, namely: (1) human capital, which is a personal power indicated by the character, education and previous 
experience; (2) social capital, which is a pleasant social environment derived from family and spouse, and built social network; and (3) reputational capital, which is a social image of the figure of entrepreneurs. This is indicated by award-winning from other agencies or having a certain reputation in business.

Some other researchers, such as Hoyos (2011), Huarng, Tur and Yu (2012), Javadian and Singh (2012), and Saputri and Himam (2015) described two factors which influence entrepreneurial success, such as personal and situational factors. While personal factors can be referred to as the motive, intellectual, skills, character, perception, self-efficacy and others related to personality, the situational factors are influenced by the condition of the surrounding environment. Managerial skill in terms of the ability to plan and strategize, cooperate, communicate and manage personnel is also another important factor contributing to the success of an entrepreneur (Benzing, Chu \& Kara 2009; Hellriegel, Jackson \& Slocum 2016).

It is a fact that entrepreneurs are not born but are formed. Therefore, the development of personality with the ability to adapt to the environment that causes the entrepreneurial spirit was formed, not because of being born as a factor of heredity or talent (Hellriegel et al. 2016). There are indeed entrepreneurs who only continue the efforts of previous generations, but if they do not have the personality attributes of entrepreneurship, technical skills and managerial skills, then the effort will slowly crumble. As the phrase is often heard, that the first generation finds, the second generation enjoys, and the third generation destroys.

Sinha (2003) proposed three categories of female entrepreneurs in terms of the main reason in becoming an entrepreneur, such as chance, forced, and created entrepreneurs. A chance entrepreneur is an entrepreneur who starts her business without any significant plan and purpose. The business commonly begins with a hobby which later develops into an economical business as time goes by. Forced entrepreneur is an entrepreneur who is forced by circumstances, such as the death of a husband or the insistence of economic factors so they are forced to become entrepreneurs because of financial needs. Meanwhile, created entrepreneurs are entrepreneurs who are planned, motivated and developing through various entrepreneur development programs. Created entrepreneurs do intend and prepare to become entrepreneurs so they have systematic steps.

Of the different categories, each will influence differences in perceiving the meaning of success. The different perceptions of success will affect their behavior in running their business. This, in turn, may help us to better understand why entrepreneurs create and develop their business in different ways (Fauchart \& Gruber 2011; Sieger, Gruber, Fauchart \&, Zellweger 2016).

\section{Method}

According to the data obtained from the Agency of Cooperatives and Small and Medium Enterprises, Province of Jambi (Tribun Jambi October 18, 2017), there were 98,105 SMEs in Jambi Province scattering in 11 districts. Of the number of SMEs, there were 85,684 micro businesses, 11,169 were small businesses and the remaining 1,252 were medium enterprises. 
As for the city of Jambi itself, there were 10,588 units of SMEs listed, consisting of 8,469 micros scaled, 1,765 small-scaled and the remaining 354 of medium scaled. The data shows that micro-scale enterprises dominated SMEs in the provinces and cities of Jambi. From the micro scaled business, culinary sector was the most emerging sector. Upon that reason, the participants of this study were chosen from culinary sectors.

The present research used qualitative method with case study approach based on exploratory demands. It aimed to understand and explain the meaning of success, the influential factors, and the solution model of success for small-scaled and micro-entrepreneurs as the focus of this study.

The participants in this research were small and micro-scaled entrepreneurs residing in Jambi Province. Samples were taken on the basis of non-probability sampling which means not to provide equal opportunity for every member of population to be selected as a sample. This means that the findings of this study cannot be confidently generalized to the population (Sekaran \& Bougie 2016). The sampling technique used was purposive sampling, by which the selection of samples was performed based on certain considerations. They are micro-small entrepreneurs who have been running their business at least for five years at the time of data gathering. The products they produce have a brand image, displayed in supermarkets and the marketing range has expanded to the province or outside Jambi.

Based on the initial survey, there are four entrepreneurs who meet these criteria, namely the owner of rempeyek Ilham, Amanah, Ridho cake and R \& R. As such, these four creative entrepreneurs were positioned as key informants. All of the informants are also active in the organization of the Association of Food and Beverage Industry (ASMAMI) Jambi, which was established in 2015. Other informants regarded as complements were family members or employees involved in their daily business activities.

Semi-structured interviews, observation, documentation study and the combination of all three or triangulation are utilized in collecting data. The interviews investigated understanding of success by entrepreneurs through five open-ended questions adopted by Angel, Jenkins and Stephens (2018): (1) 'What were your initial motivations to become an entrepreneur? (2) 'Can you describe how your business has developed from its founding to where it is today?, (3) 'How has the process of developing your business influenced your motivations and goals? (4) 'What does success as an entrepreneur mean to you?' and (5) what factors influence your success? The interview was being recorded and later on being transcribed. Then, Triangulation data were obtained by re-examining the interview transcript. Subsequently, the data were brought in a group discussion with several lectures who often conduct research on entrepreneurship and small business enterprises in Province of Jambi.

\section{Results}

\section{Respondents' characteristics}

The following table presents the characteristics of the respondents based on their demography. 
Table 1. Characteristics of Respondents Based on the Demography

\begin{tabular}{lllll}
\hline No & Owner & Age & Education & Years begin an endeavor \\
\hline 1 & Zaitun & 46 & Senior High School & 2004 (14 Years) \\
2 & Ico Ordiana & 51 & Senior High School & 2012 ( 6 Years) \\
3 & Lily Suarni & 42 & Undergraduate & 2013 (5 Years) \\
4 & Andayani & 50 & Senior High School & 2008 (10 Years) \\
\hline
\end{tabular}

Table I indicated that the average respondents are at the age of 47 with senior high school level education. They also have their businesses more than five years and older. Their position is as the owner, workers and managers of their own company assisted family members.

The following table presents the characteristics of the respondents based on their products advantages.

Table 2. Characteristics of respondents based on the product advantages

\begin{tabular}{lllll}
\hline No & Brand Name & Address & \multicolumn{1}{c}{ Product type } & \multicolumn{1}{c}{ Product advantages } \\
\hline 1 & Rempeyek Ilham & Payo Lebar & Various crisps & Various flavors of crisps \\
2 & Amanah & Telanai Pura & Various cake & Fish-based products \\
3 & Ridho cake & TalangBanjar & Pastries & Low to medium price \\
4 & R \& R & Kp. Manggis & $\begin{array}{l}\text { Spongcake, squash, } \\
\text { spinach crisp }\end{array}$ & Vegetables derived \\
& & & products \\
\hline
\end{tabular}

Table 2 describes that each respondent also has a different flagship product although they are involved in the same business sector; culinary.

\section{Findings}

\section{Rempeyek Ilham}

Zaitun, the owner of Ilham rempeyek started to operate her business in 2004. Initially, she began with her desire to help the family living, encouraged with her persistence in experimenting to create the mainstay products ranging from traditional cakes such as lumpang, donuts, and risoles to other various kinds of cake until she finally decided to focus on producing crisps. It was based on her sales experience that the crisps were the product the most buyers were interested in.

In her view, success needs to be fought for with a lot of efforts. After going through a long journey and undergoing several failures, eventually, rempeyek Ilham managed to penetrate a number of supermarkets in Jambi, Palembang and even Pekanbaru. Nowadays, rempeyek Ilham has its own dedicated display shelves in supermarkets and its own customers from outside Jambi. When asked whether she was satisfied with the current conditions she has achieved, she replied with the following quote:

"In terms of material aspect, from the state of homeless and no car, now have them already. In fact, I can perform umroh. At first, that was a success for me. Success for 
me now because it can help people, can hire people around the place of business, and can be free from bank loans."

From the interview quote, it is obvious that initially, success is measured from the ownership of materials to meet the necessities of life such as homes and cars possession. Her business is initially motivated by her intent to support her family living. Later on, when these basic necessities have been met, the meaning of success to her is to perform umrah and pilgrimage to Mecca. When material ownership has been established, the meaning of success shifts subjectively to inner satisfaction because she is able to help provide jobs for others, able to help others and enjoys financial freedom without bank debt. In addition, Zaitun is pleased when being invited to be a speaker to share her knowledge and experience in various trainings and seminars on entrepreneurship. Therefore, there are three sequences of success. First, starting with financial success which is marked by the ownership of financial needs. Next, psychology success which is marked by the satisfying and happy feeling of sharing and giving. Last, social success which is marked by fame or being known as guest speakers in workshops because of the success.

In achieving her goal, Zaitun explained several factors which influenced her success, as follows:

1. Personal attributes. Persistence, not easy to give up, not ambitious to gain short-term profit, creative to invent distinctive products than others are among of basic requirements for an entrepreneur.

2. Support from spouse and family. In accordance with her nature of a wife and a mother, Zaitun recognizes support from her husband and family to back up her in doing business. Her husband working as a civil servant, backs up in marketing and distributing her products, so does her eldest son, Ilham.

3. Workers' loyalty. The employees who are neighbors around her house are highly dedicated to their employer. This is proven with the workers have been working since the early period of the business. Although Zaitun implements the concept of openness in what she uses, her employees remain loyal to working with the production standards they set. She always treats her employees like her own family and she expects that in the future, they will also open their own business. She is not afraid of competing; instead, she really believes that everyone has their own fortune.

4. Local government assistance. Zaitun also realizes the supports of local governments, such as assistance in provision of equipment, training, providing opportunities to attend various trainings and exhibitions as well as government policies to use snacks produced by SMEs in various government events which have a significant contribution for her success.

From the interview results, it can be concluded that the factors contributing to success begins with herself, her husband and family supports, loyal employee and governmental aid. 


\section{Amanah}

The business owner of 'Amanah' is Mrs. Ico Ordiana, who initially started from her hobby to create a variety of pastries and wet cake which have been done since she was a girl and resided in Jakarta. When she was married in 1989 and had to move to Jambi following her husband, Mrs. Ico continued her hobby of making cake and delivering it to shops around the house. The business she runs also experienced some challenges, until one day she attended a snack processing course made from fish as raw material organized by the Fisheries Agency. Having attended the training for three consecutive years, she experimented to create a flagship product and finally in 2012, the product of rengginang made of raw fish was launched. To date, Mrs. Ico used fish as raw material for all their products, such as catfish abon, sambal lingkung, crispy skin of cork fish and fish rengginang.

The marketing of Amanah branded products (since the address of her production house is on Amanah Street) has successfully penetrated a number of supermarkets in various cities, such as Jambi, Palembang, Medan, Pekanbaru and even Jakarta. Furthermore, her flagship product, fish rengginang becomes favorite snack of Mr. Susilo Bambang Yudhoyono (former president of Republic of Indonesia) who once came to Jambi for the purpose of the press monument inauguration in 2012 and to date, the order still continues to regularly be made.

Another achievement is that she once was included in the finalists of 20 best recipes in Indonesia out of 350 participants in event of product innovation contest from Fishery Agency of Republic of Indonesia. Today, the Amanah's sales turnover can reach Rp. 6 million per day.

In line with Zaitun, Mrs. Ico also acknowledges that financial success, particularly in home and private cars ownership is a measure of the success of her business at an early stage. Now, in her view, the meaning of success is that she can successfully provide jobs for others. In addition,she also added that success also means being able to share knowledge and experience as resource persons through various entrepreneurial trainings and seminars.

According to her, her success is determined by several following factors:

1. Personal character. In order to be successful, the person is required to never give up, be patient, be always grateful for what is gained and continuously learn. These are the main factors which keep her in managing various challenges and obstacles in her business.

2. Involvement or participation in professional organizations. Ico is a member and one of management of ASMAMI (The Food and Beverage Industry Association), an association which has members of food and beverages producing entrepreneurs. The organization provides regular meeting for sharing experiences among fellow entrepreneurs every month.

3. Support of the spouse and family; Ico's husband and children also support her business both morally and physically.

In the end of the interview, Ico also emphasizes that personal characteristics are the main factor influencing the success. Based on her personal experience, she realizes that in 
entrepreneurship, they will face many competitors, have the risk of fails since the success cannot be achieved immediately. Therefore, a person who never gives up, being patient and always grateful and continuously learns is the main attribute in achieving entrepreneurial success.

\section{Ridho Cake}

Forced by economic demands, Mrs. Suarni started her business in 2013. With continuous self-taught, she practiced making a sponge cake until she was finally able to penetrate supermarkets in the city of Jambi, Muaro Jambi and even Sabak. With her flagship product of various sponge cakes, Suarni used the brand "Ridho Cake" and began to be recognized by the public until many consumers buy directly to her home. The regular customer is the Mayor of Jambi for religious event held every Friday night.

When asked whether she already felt successful with what she has achieved, the following excerpts are interviews with Mrs. Suarni.

"Yeah, initially no vehicle possession, now I have my own. But now with great gratitude that this business can meet the needs of the family and be able to hire others, that's what success means to me."

Since her business has only been running for 5 years, the meaning of success to Suarni is seen merely in financial aspect. This is in accordance with her motivation of being an entrepreneur, which is to help improve family income. According to her, the factors which influence her success are as follows:

1. Personal character. In her view, to be an entrepreneur, they must have confidence that success is attainable, being not discouraged and willing to share knowledge with others.

2. Generosity. Suarni has a strong belief that giving a lot will get a lot of reward.

3. Being responsive to buyer complaints. Disappointed buyers will certainly not make repeat purchases. Therefore, she always serves her buyers wholeheartedly and is responsive to complaints from them, especially her customers. The loyal customers will maintain her business sustainability.

Suarni always gives bonuses to customers who buy in large quantities as a strategy in order to establish loyal customers. The product segmentation has also been done to her spongecake according to the level of purchasing power of the consumers. There are economy-class sponges, standard and executive class ones.

\section{$\mathbf{R} \& \mathbf{R}$}

As a resigning employee, Andayani was then determined to start her own business by creating snack, like spinach crackers in 2007. A year later, she registered her product to obtain home industry product registration (P-IRT) under the R \& R brand. Currently, her products have managed to penetrate several supermarkets in Jambi and Palembang. In addition, her products have been developed into four kinds beside spinach crackers, namely tofu prawn crackers, rempeyek kribon and squash chips. 
Unlike the three previous respondents who became entrepreneurs because of having to improve their family income, the early motivation of Andayani to become an entrepreneur is to take up her hobby in cooking. In addition, she also wanted to have a freedom to manage her own time. Before being an entrepreneur, she already had financial assets, such as private homes and cars. Thus, to her, success means more to the future success of her sons and her ability to help her family.

To achieve success in business, Andayani explained the following factors:

1. Being eager to share knowledge with everyone. Andayani will always grant employees or everyone who comes to ask about the recipe. In fact, she is not afraid that competitors will copy the recipe. She believes in saying that everyone has their own sustenance and to get the abundance of wealth, there should be a lot of charity.

2. Personal character. Conducting business must be accompanied by deep interest from the heart, having ideas to improve, and honesty.

\section{Discussion}

Of the four entrepreneurs who have been interviewed, there is a common perspective regarding the meaning of success which is initially measured objectively from financial success in form of material ownership, such as houses, vehicles, and the ability to perform the umroh to Mecca. Once the financial success has been established, the meaning of success shifts subjectively to psychological success in form of inner satisfaction, such as feeling satisfied of having provided employment for other, help and share goodness with others and family. After accomplishing financial aspect, success will be perceived when one becomes well-known in society as a speaker in many workshops.

This finding is in line with the results of previous researchers' studies (Benzing et al. 2009; Baruch 2006; Abele \& Spurk, 2009; Amin, 2012) which conclude that success will firstly be viewed objectively by the measure of ownership of financial assets such as houses, vehicles, deposits in banks and its kind. After financial success is achieved, the meaning of success will shift to psychological aspects, such as inner satisfaction towards the achievements that have been achieved and succeed in hiring others. However, since the participants of this study are not comes from well-known public figures, the frequency of being invited as a speaker to share their business experiences in many workshops and conferences will be a parameter for the social success.

Success is everyone's aspiration; thus, the perception on the meaning of success will affect individual's behavior to achieve his/her goals. For instance, a person who perceives that the measure of success based on the financial aspect, he/she will be motivated to work to gain the financial aspect as much as to be said successful. Likewise, people who have a perception that the measure of success is a balance between career and family, they will work not only to pursue the financial aspect alone, but they also consider the time management and togetherness with family.

Based on the results of this study, it indicates that success will initially be perceived through 
the achievement of the fulfillment of material needs, such as houses and vehicles ownership; furthermore, performing umrah and hajj pilgrimage. At this stage, it is what is called financial success. Once these needs of material aspects are established, the subjective measures shift to the achievement of the fulfillment of psychological needs, such as feeling of satisfaction of being able to hire others. Moreover, it is also found that positive aspects of the respondents' character are the common belief that giving more the others will result in gaining more rewards from the Almighty.

Here's a summary of the results of research which becomes a model of success in this study:

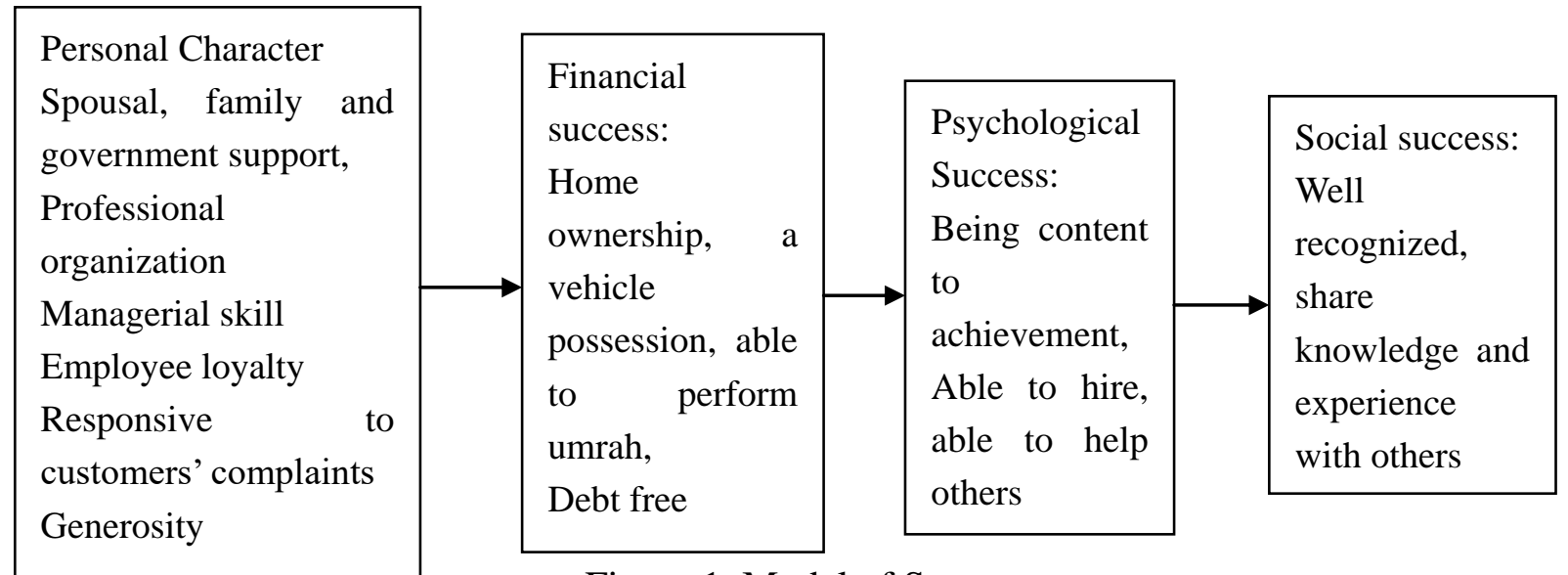

Figure 1. Model of Success

Source: the result of this study

This phenomenon indicates there are three meanings of success, namely financial success, in the form of material property ownership, psychological success in the form of inner satisfaction because it has achieved desired outcomes and can employ other people and social success because it has been known by many people and can share knowledge and experience as resource person in various trainings and seminars. Thus, social success is regarded as the highest measure of success, which can only be achieved if financial and psychological success have been attained.

The findings of this study are different from the previous research that was conducted by Angel et al (2018). They used four main criteria in measuring the success of entrepreneur, such as personal fulfillment, customer relationship, community impact and firm growth. Another study by Ahmad, Wilson and Kummerow (2011) concluded that SME owners in Malaysia perceived business success in terms of (a) satisfaction with nonfinancial performance, (b) satisfaction with financial performance, (c) performance relative to competitors and (d) business growth. Meanwhile, the participants' responses of this study focused on personal fulfillment and community impact. It happened because the participants' background in becoming entrepreneur is caused by financial factor (forced entrepreneur), and their business is still categorized as micro scale.

There are several factors which influence the success of entrepreneurs of small and medium enterprises. However, all respondents acknowledged that the underlying factor for success is the character of self-creativity, persistence, patience, and always being grateful for what has 
been gained. Managerial skill also contributes to the success, especially in managing the employee. Treat employees as own family, nurturing charity and be grateful for what has been obtained are the managerial skills that the respondent conducting. Since the respondents are graduates from senior high school, the role of management skill is required for their significant success.

In addition, spousal support and family support in term of moral support or their involvement to the business are the factors influence the success. Government support in term of the policy or the other is also influence the success.

\section{Conclusion}

It is well acknowledged that success cannot be obtained instantly. The meaning of success begins with an increase in the financial aspects, such as home and vehicles ownership, able to perform umroh and then shifted to psychological success in form of inner satisfaction, such as being able to hire people, able to help others, and able to share with others. Finally, after financial and psychological success have been achieved, social success is a further stage, such as being well recognized and having the opportunity to be a source to share knowledge and experience in various training activities and seminars. The findings indicated that the perceptions of success meaning will affect the way entrepreneur run their business for accomplishment of personal needs and benefits for society.

The respondents in this study have proven that their success is achieved through a long journey that requires (1) personal characters to be creative, persistence, patient, and self-assured; (2) environmental support in the term of spousal, family and government support, and participation in business organizations; and (3) managerial skill in term of the ability to manage employee and customer, and the knowledge about the field of business to be involved in. Understanding these factors will predispose strategies for achieving success and optimizing the role of those supporting factors.

\section{Acknowledgement}

The authors are grateful to DIPA PNBP LPPM Universitas Jambi 2018 for funding the research.

\section{References}

Abele, A. E., \& Spurk, D. (2009). How do objective and subjective career successes interrelate over time? Journal of Occupational and Organizational Psychology, 82, 803-824. 2009. https://doi.org/10.1348/096317909X470924

Afiff, F. (2012). Kewirausahaan dan Ekonomi Kreatif. Rangkaian Kolom Kluster I. Binus University

Ahmad, N. H., Wilson, C., \& Kummerow, L. (2011). Assessing the Dimensionality of Business Success: The Perspectives of Malaysian SME Owner-Managers. Journal of Asia-Pacific Business, 12(3), 207-224. https://doi.org/10.1080/10599231.2011.586855

Alam, S. S., Jani, M. M., \& Omar, N. A. (2011). An Empirical Study of Success Factors of 
Women Entrepreneurs in Southern Region in Malaysia. Internal Journal of Economics and Finance, 3(2), 166-175. https://doi.org/10.5539/ijef.v3n2p166

Amin, S. (2012). Does Work Life Balance Predict to Career Success? International Journal on Social Science, Economics \& Arts, 2(1).

Angel, P., Jenkins, A., \& Stephens, A. (2018). Understanding entrepreneurial success: a phenomenographic approach. International Small Business Journal: Researching Entrepreneurship, 1-26. https://doi.org/10.1177/0266242618768662

Baruch, Y. (2006). Career development in organizations and beyond: balancing traditional contemporary viewpoints. Human Resource Management Review, 16, 125-138.

https://doi.org/10.1016/j.hrmr.2006.03.002

Benzing, C., Chu, H. M., \& Kara, O. (2009). Entrepreneurs inTurkey: A FactorAnalysis of Motivations, SuccessFactors, and Problems. Journal of Small Business Management, 47(1), 58-91. https://doi.org/10.1111/j.1540-627X.2008.00262.x

Brindley, C. (2005). Barriers to womern achieving their potential: Women and risk. International Journal of Entrepreneurial Behaviour and Research, 11(2), 144-161. https://doi.org/10.1108/13552550510590554

Carland, J. W., Hoy, F., Boulton, W. R., \& Carland, J. A. C. (1984). Differentiating Entrepreneurs from Small Business Owners: A Conceptualization. Academy of Management Reviefounder identity in entrepreneurship. Academy of Management Journal, 54(5), 935-957.

Fisher, R., Maritz, A., \& Lobo, A. (2014). Evaluating entrepreneurs' perception of success. International Journal of Entrepreneurial Behavior \& Research, 20(5), 478-492. https://doi.org/10.1108/IJEBR-10-2013-0157

Global Entrepreneurship Monitor (2010). 2010 Women's report.

Goyal, M., \& Parkash, J. ( 2011). Women Entrepreneurship in India-Problems and Prospects. International Journal of Multidisciplinary Research, 1(5), 195-207.

Hadiyati, E. (2010). Marketing for SMEs: Theory and Applications, Malang: Bayumedia Press.

Hellriegel, D., Jackson, S. E., Slocum, Jr, J. W. (2016). Management A Competency-Based Approach, Edition 11, International Student Edition Thomson-South-Western.

Heslin, P. A. (2005). Conceptualizing and evaluating career success. Journal of Organizational Behavior, 26, 113-136. https://doi.org/10.1002/job.270

Hoyos, M. (2011). Entrepreneurial Success: Interplay Between Sistemic and Individual $\begin{array}{llll}\text { Factors Nia } & \text { Vetworking }\end{array}$ http://sbaer.uca.edu/research/icsb/2012/De\%20Hoyos\%20450.pdf\#page=1\&zoom=auto, 0,79 2

Huarng, K., Tur, A., \& Yu, T. (2012). Factor Affecting the Success of Women Entrepreneurs. 
Int Entrep Manag Journal, 8, 487-497. https://doi.org/10.1007/s11365-012-0233-4

International Finance Corporation. (2016). UKM yang dimiliki wanita di Indonesia: Kesempatan Emas untuk Institusi Keuangan Lokal. Studi Penelitian Pasar, 1-84.

Javadian, G., \& Singh, R. (2012). Examining Successful Iranian Women Entrepreneurs: An Explatory Study. Gender in Management: An International Journal, 27(3), 184-164. https://doi.org/10.1108/17542411211221259

Jenkins and Stephens. ( 2018). Understanding Entrepreneurial Success: A phenomenographic approach International Small Business Journal; Researching Entrepreneurship. https://doi.org/10.1177/0266242618768662

Jennings, J. E., \& Brush, C. G. (2013). Research on Women Entrepreneurs: Challenges to (and from) the Broader Entrepreneurship Literature? The Academy of Management Annals, 7(1), 663-715. https://doi.org/10.1080/19416520.2013.782190

Kurniawan, A., Jalaludin, A., \& Hastuti, S. (2014). Permasalahan Kompetensi Pelaku Usaha Kecil Bidang Kuliner di Kota Bandung dan Kota Cimahi. The $7^{\text {th }}$ NCFB and Doctoral Colloquium. Fakultas Bisnis dan Pascasarjana UKWMS.

Mabhungu, I., \& Poll, B. (2017). A Review of Critical Success Factors Which Drives the Performance of Micro, Small and Medium Enterprises. International Journal of Business and Management, 12(6), 2017. https://doi.org/10.5539/ijbm.v12n6p151

Mat Rashid, K., Che Ngah, H., Mohamed, Z., \& Mansor, N. (2015). Success Factors Among Women Entrepreneur in Malaysia. International Academic Research Journal of Business and Technology, 1(2), 28-36.

Nandy, S., \& Kumar, S. (2014). Women Entrepreneurship in $21^{\text {st }}$ Century India. Global. Journal of Finance and Management, 6(9), 967-976.

Park, Y. (2010). The predictors of subjective career success: an empirical study of employee development in a Korean financial company. International Journal of Training and Development, 14, 1-15. https://doi.org/10.1111/j.1468-2419.2009.00337.x

Raman, K., Anantharaman, R. N., \& Jayasingan, S. (2008). Motivational Factors Affecting Entrepreneural Decision: A Comparison between Malaysian Women Entrepreneurs and Women Non Entrepreneurs. Communication of IBIMA, 2, 85-89.

Saputri, R. K., \& Himam, F. (2015). Mindset Wanita Pengusaha Sukses. Jurnal Psikologi, 42(2), Agustus 157-172. https://doi.org/10.22146/jpsi.7170

Sarri, K., \& Trihopoulou. (2005). Female Entrepreneurs' Personal Characteristics and Motivation: A Review of the Greek Situation. Women in Management Review, 20(1), 24-36. https://doi.org/10.1108/09649420510579559

Sekaran, U., \& Bougie, R. (2016). Research Methods for Business, A Skill Building Approach, Seventh Edition, John Wiley \& Sons Ltd Tribun Jambi, Oktober 18, 2017. 


\section{Macrothink}

International Journal of Human Resource Studies

ISSN 2162-3058 2019, Vol. 9, No. 4

Sieger, P., Gruber, M., Fauchart, E., \& Zellweger, T (2016) Measuring the social identity of entrepreneurs: Scale development and international validation. Journal of Business Venturing 31(5), 542-572. https://doi.org/10.1016/j.jbusvent.2016.07.001

Sinha, A. (2003). Experience of SMEs in South and South-East Asia, Washington, D.C. SEDF and World Bank.

Srikanth, P. B., \& Israel, D. (2012). Career commitment \& career success: mediating role of career satisfaction. The Indian Journal of Industrial Relations, 48(1), 137-149.

Zimmerer, T., \& Scarborough, N. M. (2008). Kewirausahaan dan Manajemen Usaha Kecil. Salemba Empat. Jakarta.

Zimmerman, J. L., \& Jiang, Z. S. (2009). Entrepreneurial Motivation: A Case Study of Scale Entrepreneurs In Mekell, Ethiopia, Journal of Business Management \& Social Sciences Research.

\section{Copyright Disclaimer}

Copyright for this article is retained by the author(s), with first publication rights granted to the journal.

This is an open-access article distributed under the terms and conditions of the Creative Commons Attribution license (http://creativecommons.org/licenses/by/4.0/). 